\title{
17. celostátní archivní konference v Liberci
}

Archivářky a archiváři z Čech, Moravy i zahraničí zamírili na konci dubna na své tradiční setkání tentokrát na sever Čech. Již sedmnáctá celostátní archivní konference se uskutečnila ve dnech 25.-27. dubna 2017 v prostorách libereckého hotelu Babylon. Pod záštitou náměstka Ministerstva vnitra Petra Mlsny, radní Libereckého kraje Květy Vinklátové, primátora statutárního města Liberec Tibora Batthyányho a rektora Technické univerzity v Liberci Zdeňka Kůse ji uspořádala Česká archivní společnost, z. s. spolu s dalšími šesti institucemi.

Liberecká konference navazovala na předchozí ročníky archivních konferencí, přesto byla svým způsobem revoluční, nebot' její organizátoři zvolili výrazně odlišný př́stup. Zatímco minulá setkání reflektovala především témata vztahující se k místu konání a organizátorským archivům, liberecké setkání nabídlo nový model. Historicky největší setkání archivářù, kterého se zúčastnilo 420 registrovaných účastníků, přineslo rozdělení jednání do paralelně probíhajících sekcí a blokủ, které byly jednoznačně tematicky orientovány. Většina př́spěvkủ vznikla na základě přímého oslovení referujících, což mělo za následek ucelenější podobu většiny bloků a přispělo $\mathrm{k}$ výraznějšímu profilování konference.

Jednotlivé sekce a bloky se věnovaly dvěma hlavním tematickým okruhům. První Německá okupační správa v letech 1938 až 1945 - byl tradičně monotematický a souvisel s místem konání a odborným zájmem archivářu z pořadatelských archivů. ${ }^{1}$ Druhý tematický okruh byl vymezen volněji a nabídl př́spěvky $\mathrm{k}$ řadě aktuálních témat současného archivnictví.

V rámci bloku Německá okupační správa v letech 1938-1945 byly předneseny téměř dvě desítky př́spěvků českých, polských i německých archivářů a badatelů, které sledovaly několik základních tematických okruhů. První skupina př́spěvků přinesla biografické zprávy o některých významných či zajímavých regionálních osobnostech (např́klad Eduard Mikušek hovořil o archiváři ve vedení Sudetské župy Kurtu Oberdofferovi, Zdeněk Kravar o opavském vládním prezidentovi Fridrichu Zippeliovi či Michal Rádl o starostovi České Lípy Josefu Thurnerovi). Dále měli posluchači možnost vyslechnout několik referátů, zaměřených na okupační správní úřady (tř̌eba referát Jiř́ho Smitky o Pozemkovém úřadu pro Čechy a Moravu v Praze, Jozefa Šerky o Městském úruadu v Moravské Ostravě či Moniky Sedlákové a Zdeňky Kokoškové o úřadech oberlandrátů v systému okupační správy Protektorátu Čechy a Morava). Obecně oblasti archivnictví se o něco více týkaly př́íspěvky podávající přehledy pramenů $\mathrm{k}$ dějinám německé okupační správy, uložených v českých, polských a německých archivech (např́klad Stefanie Jostová seznámila s pramennou základnou německého Bundesarchivu či Ingrid Sauerová se situací v bavorském

1 Organizátory 17. celostátní archivní konference byly Česká archivní společnost, z. s., Česká informační společnost, z. s. - pobočný spolek při Národním archivu, Státní oblastní archiv v Litoměřicích, Státní okresní archiv Liberec, Státní okresní archiv Jablonec nad Nisou, Ještědská pobočka České archivní společnosti a Katedra historie Fakulty př́rodovědně-humanitní a pedagogické Technické univerzity v Liberci. 
Hauptstaatsarchivu; Miroslav Eisenhammer zase hovořil o archivních fondech organizací zajišt'ujících protileteckou ochranu v protektorátu). K zajímavým př́spěvkům se bezesporu řadí také zprávy o výzkumných projektech archivů a badatelských institucí, at' už se jednalo o př́spěvek Zdeňky Kokoškové, která představila projekty Národního archivu, nebo Marka Poloncarze, jenž hovořil o projektech Státního oblastního archivu v Litoměřicích.

Příspěvky prvního bloku přinesly nejenom celou řadu konkrétních informací o pramenné základně, aktuálně probíhajících badatelských projektech či o výsledcích již uzavřených výzkumů v oblasti německé okupační správy (co se institucí i jednotlivců týče), ale především v rámci širších tematických souvislostí vycházejících z praxe pořadatelských archivů zdůraznily průběh a možnosti přeshraniční spolupráce a předávání zkušenosti z výzkumů a vzájemného poznávání. Akcentovaly tak jeden z aktuálních trendů současného archivnictví - dưraz kladený na mezinárodní a meziinstitucionální spolupráci.

Př́iklady a témata $\mathrm{z}$ regionů však pronikly i do dalších konferenčních bloků. Konkrétně především do setkání Radany Červené (Archiv města Brna), Ivo Habána (NPÚ), Ivy Svitkové (PedF JEP) a Marka Lašt'ovky (Archiv hl. m. Prahy) k tématu vydavatelské spolupráce pamět’ových institucí. Původní záměr pořadatelů rozvinout diskuzi nad otázkami možností a forem institucionální spolupráce na poli vydavatelských aktivit sice nebyl zcela naplněn, nebot' program se vyvinul spíše do podoby prezentací jednotlivých vydavatelských projektů, a to jak odborné literatury a periodik (brněnského archivu, Archivu hlavního města Prahy, Scriptoria, spolku pro nekomerční vydávání literatury, regionálního časopisu Fontes Nissae), tak historických pramenů (konkrétně projektu Libri civitatis, zabývajícího se katalogizací a edicemi městských knih). Účastníkům této části konferenčního programu se však nabídla zajímavá možnost nahlédnout do zákulisí celé řady pozoruhodných vydavatelských projektů. $V$ závěrečné diskuzi pak mohli účastníci konference sledovat, jaké problémy pamětové instituce $\mathrm{v}$ souvislosti se svou vydavatelskou činností vnímají jako nejpalčivější, at' již se jedná o problematiku distribuce a elektronizace či ryze praktické otázky autorských honorářŭ, grafické podoby, periodicity vydávání či podmínek pro zařazení na seznamy recenzovaných periodik.

Sekce druhého programového bloku, věnovaného aktuálním trendům českého archivnictví, částečně navazovaly na otázky probírané na předchozím celostátním setkání archivářů v Poděbradech v roce 2015, řada diskutovaných témat však byla nová.

Programový blok otevřela panelová diskuze na téma „České archivnictví - kudy dál?“, které se zúčastnili Tomáš Dvořák z Archivu hlavního města Prahy, náměstek ministra vnitra pro legislativu a archivnictví Petr Mlsna a ředitel odboru archivní správy ministerstva vnitra Jiř́ Úlovec. Diskutující představili dvě aktuální dlouhodobé koncepce českého archivnictví. První, kterou přibližil Tomáš Dvořák, vznikla na půdě České archivní společnosti, druhá je výsledkem pracovní skupiny zaštítěné odborem archivní správy Ministerstva vnitra. Ohlas vyvolala zejména posledně jmenovaná koncepce. Jednoznačně potěšujícím výsledkem diskuze je aktivní zájem vedení ministerstva o problémy a rozvoj českého archivnictví. Petr Mlsna se nejen při této př́ležitosti projevil jako odborný náměstek ministra $\mathrm{v}$ tom nejlepším slova smyslu a jeho živý odborný zájem může pomoci českému archivnictví dostat se z „druhé koleje“ české veřejné správy. Ne všechny prezentované vize se však setkaly s pozitivním ohlasem. Pracovníci státních okresních archivů reagovali na plány ohledně zvýšení efektivity státních archivů a na v té souvislosti otevíranou otázku možné redukce (koncentrace) archivní sítě. Nutno rovněž zdůraznit, že zástupci Ministerstva vnitra se ve 
svém výkladu soustředili zejména na roli státních archivů ve veřejné správě, což je trend, který byl relativně nedávno podpořen zařazením archivářu do státní služby a posílením postavení státních archivů jako správních úřadů. Role archivů mimo státní sít' (tedy především městských, specializovaných a soukromých archivů) je v představených koncepcích českého archivnictví nejasná a oba ministerští úředníci je v podstatě představili jako „,ědictví minulosti“, se kterým si př́liš nevědí rady.

Jádro českého archivnictví a zabezpečení péče o národní archivní dědictví dle ministerské koncepce spočívá v činnosti specializovaných správních úřadů (státních archivů) a odborných státních úředníků (archivářů státních archivů), kteří začleněním do státní služby získali potřebné kompetence a brzy snad budou mít k dispozici i dnes často chybějící prostředky. Mimo tento systém však zůstávají nestátní archivy a další instituce pečující o významnou část českého archivního dědictví (vyjádřeno v běžných metrech pečují státní archivy jen o cca $80 \%$ z celkových přibližně 826 kilometrů archiválií uložených v českých archivech). Faktická dvojkolejnost a opomíjení nestátních archivů a archivářů v ministerské koncepci se staly předmětem vzrušené debaty, během níž diskutující z řad archivářů městských a specializovaných archivů upozorňovali na opomíjení jejich role v navrhované koncepci českého archivnictví.

Nestátní archivy a jejich zaměstnanci pochopitelně nemají a nemohou mít postavení správních úřadů a státních úředníků, přesto musí zajistit stejně kvalitní péči o archiválie a vykonávat stále větší množství úkolů kladených na ně státní správou. Na plnění úkolů uložených státní správou navíc většina těchto archivů (respektive jejich zřizovatelů) nedostává žádné prostřredky. Také diskutující zástupci státních archivů vnímali určenou roli státních úředníků s jistými výhradami. $\mathrm{V}$ představené koncepci postrádali především ukotvení dalších rolí archivů, které jsou nejen správními úřady, ale často také důležitými vědeckými historickými institucemi i místními osvětovými a kulturními centry.

Celkový výsledek diskuzního panelu byl přesto optimistický, nebot' přinesl pocit, že archivnictví v České republice přestává být outsiderem, na kterého si vedení Ministerstva vnitra vzpomene maximálně př́i hledání možnosti úspor a škrtů v oblasti financování.

Další aktuální blok liberecké konference byl věnován tématu edukace v archivech. Své př́íspěvky představili zástupci českých a zahraničních archivů (Státního oblastního archivu v Praze, Archivu bezpečnostních složek, Státního archivu v polských Kielcích, Mad’arského národního archivu a katedry archivnictví Vratislavské univerzity). V př́spěvcích i následné živé debatě byl akcentován rozměr archivní práce, který byl účastníky předchozí panelové diskuze upozaděn. Pozitivní, často nadšené přijetí př́spěvků jednoznačně prokázalo, že byt je tato „neúřední a nesprávni““ část práce archivů v dlouhodobých koncepcích (a i financování) archivnictví opomíjena, velká část archivářu si ji bere za svou a vykonává ji s nadšením a ztotožňuje se s ní často raději než s rolí státních úředníků.

Své místo mezi aktuálními tematickými bloky měla také otázka aplikace nových základních pravidel pro zpracování archiválií. Představeny byly první zkušenosti s implementací a testováním nového pořádacího softwaru ELZA. Přednesené př́spěvky reflektovaly vcelku pozitivní zkušenost s novým softwarem a potvrzovaly aplikovatelnost nových základních pravidel. Následná diskuze bohužel přinesla rozporuplný dojem a konstatovala faktickou rezignaci na možnosti standardizace a prohloubení důležitých aspektů archivního popisu.

Př́nosným byl blok o ochraně osobních údajů ve světle rozhodnutí ústavního soudu. Dlouho očekávané soudní rozhodnutí ve věci možné protiústavnosti $\S 37$, odst. 6 zákona 
č. 499/2004 Sb., kterým je zpřístupněna velká část archiválií z let 1948 až 1990 bez ohledu na možný obsah osobních údajů žijících osob, dopadlo pozitivně a nedošlo tak k uzavření nejnovějších archivních fondů. Ochrana osobních údajů v archivech je přesto aktuálním tématem, a proto byla př́tomnými archiváŕi živě diskutována.

Celý okruh aktuálních témat (a vlastně i celou konferenci) uzavřela diskuze o vzdělávání archivářñ. Ta, stejně jako blok o ochraně osobních údajů, navazovala na otázky probírané na předchozí celostátní konferenci archivářů $\mathrm{v}$ Poděbradech. Tehdy diskutovaný návrh na postgraduální informačně a manažersky orientované vzdělávání zejména vedoucích pracovníků $\mathrm{v}$ archivnictví vzbudil živou debatu, která přerostla $\mathrm{v}$ emotivní obranu tradičního modelu profesní př́pravy archivářŭ, založené na studiu pomocných věd historických. Diskuze v Liberci byla méně vzrušená a více konsenzuální, všichni její účastníci zdůrazňovali nemožnost opomíjet jazykovou přípravu archivářů, shodli se však na nezastavitelném trendu rozdělení archivářské profesní př́pravy na teoretičtěji zaměřené specialisty pomocných věd historických a praktičtěji zaměřené studium archivnictví s důrazem na správu dokumentů.

I přes fakt, že velká část konference byla věnována aktuálním tématům, v celkovém vyznění konference se projevil přirozeně konzervativní charakter většiny českých archivářů (a samožrejmě také organizátorů z řad vedení České archivní společnosti). Účastníci konference tak postrádali nejaktuálnější témata, která začínají proměňovat charakter českého archivnictví. Mezi diskutovanými otázkami tak bohužel chyběly jak první zkušenosti se skartačním rrízením v elektronické podobě či s postupným náběhem klíčového informačního systému českého archivnictví (Národním portálem při NA ČR), tak zhodnocení fungování Národního digitálního archivu. Celkově však nová koncepce pravidelného setkání českých archivářů přinesla jednoznačná pozitiva, celá konference byla (přes rozdělení do paralelně probíhajících panelů) kompaktnější a pro většinu zúčastněných prínosnější než předchozí ročníky.

Bohatý a zajímavý odborný program liberecké konference byl samozřejmě doplněn neméně bohatým a poutavým programem doprovodným. Ve volných chvílích mohli účastníci konference využít služeb Centra Babylon (především místního bazénu) či vyrazit do ulic města Liberce. Své brány a expozice, včetně aktuálních výstav, jim otevřelo nejenom Severočeské muzeum v Liberci a Oblastní galerie Liberec, ale i Muzeum skla a bižuterie Jablonec nad Nisou. Turisticky zdatní jedinci se pak odvážili na organizovaný (speciální „archivní“ tramvají) i neorganizovaný (po vlastní ose) výlet na Ještěd, na jehož vrcholu je navzdory jarnímu termínu přivítal nevlídný vítr, sníh a mráz. Vyvrcholením doprovodného programu konference se pak stal společenský večer v rozlehlém sále Expo libereckého Babylonu. Př́tomní archiváři a archivářky měli v jeho průběhu možnost seznámit se s kolegyněmi a kolegy z jiných archivů či pohovořit s archiváři již známými; to vše za př́ijemného dostatku dobrého jídla i pití a za zvuků a tónů nezbytného hudebního doprovodu, který mnohé př́tomné lákal nejenom k poslechu, ale i k tanci.

Závěrem nezbývá než konstatovat, že nový model v pořadí již 17. konference archivářek a archivářů se osvědčil. Organizátorům patř́ za zdařilé setkání dík a uznání. 